\title{
アヤメ科植物によるカドミウムの吸収除去に関する研究
}

\section{A Study of Phytoaccumulation for Cd by Iris}

\author{
浅井 俊光* 宮本 れい** 水庭千鶴子** 近藤 三雄** \\ Toshimitsu ASAI Miyamoto REI Chizuko MIZUNIWA Mitsuo KONDO
}

\begin{abstract}
Recently the lower criterion on cadmium (Cd) concentrations for polished rice was suggested in CODEX. It is urgently necessary to find out the most effective phytoremediator to remove $\mathrm{Cd}$ from rice fields. We have selected Iris pseudoacorus L. and Iris ensata Thunb. for our study from the following reasons; Iris pseudoacorus L. is known for its high biomass and strong resistance to environmental impacts: Iris ensata Thunb. have been often planted in the rice field in fallow. Both species are recognized by their beautiful flowers, commonness, the low prices and the easiness of planting. This experiment is aimed to evaluate these two species as phytoremediators to remove $\mathrm{Cd}$. These plants are planted into 1ppm, 10ppm, 100ppm Cd hydroponics for 7 days. In general, $\mathrm{Cd}$ uptake by plants increases according to the $\mathrm{Cd}$ level of the hydroponics. The Cd removal rates of Iris pseudoacorus L. are between 0.64 and 2.00\% ( $/ \mathrm{DW}$ ), while those of Iris ensata Thunb. are between 0.48 and $4.33 \%$. Iris ensata Thunb. showed the higher efficiency in the low Cd concentration, whereas Iris pseudoacorus L. indicated an advantage under the high Cd concentration. Both Iris pseudoacorus L. and Iris ensata Thunb. indicate high Cd concentration in their roots but low in their shoots.
\end{abstract}

Keywords: Phytoremediator, Cadmium, Iris pseudoacorus L., Iris ensata Thunb.

キーワード：ファイトレメディエーター，カドミウム，キショウブ，ハナショウブ

\section{1. 研究の背景及び目的}

近年 CODEX 委員会によって我が国における既存の玄米中カ ドミウム $(\mathrm{Cd})$ 基準值 (1.0ppm) とは別に, 基準值を精米中に $0.4 \mathrm{ppm}$ (2005) 以下とする検討がなされている。比較的 $\mathrm{Cd}$ 濃 度の高い土㙵を保有する我が国では, 現在市場に出回っている米 の数\%が新たな污染米となり ${ }^{1)}$, 白米生産業者はもとより我が国 の経済そのものに大きな影響を与える可能性が示唆されている。 また非契煙者の場合 $\mathrm{Cd}$ 摂取の大半が食品由来であり ${ }^{2)}$ ，当然主 食である白米からの撕取量は大である。 $\mathrm{Cd}$ はカルシウム代謝の 阻害, 高カルシウム尿, 腎結石の生成を引き起こす原因物質であ るとされ, 高濃度の $\mathrm{Cd}$ 摂取は栄養上の欠陥など他の要因と共存 し, 骨粗鬆症及び骨軟化症を発症させるなど ${ }^{2}$ 可能な限り体内へ の㠌取は抑えるのが望ましい物質である。

現在, 玄米への $\mathrm{Cd}$ 吸収を抑制する手法としては客土法が一般 的かつ効果的な手法として認められているが，コストや労力の面 からファイトレメディエーションを始めとする様々な浄化手法の 開発が急務となっている。ファイトレメディエーションでは既に 様々な污染物質に対して有用な植物が挙げられているが，水田と いう特殊な環境下では生育に支障をきたす恐れや，浄化期間が長 期にわたりランニングコストやメンテナンスに大きな負担がかか

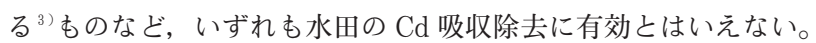
そこで本研究では河川などで栄養塩類の浄化などにも使用さ れ ${ }^{4)}$, 旺盛な生長力とバイオマスを有するキショウブ（Iris pseudoacorus L.）と実際に水田で植栽されるなど環境条件に合 致し, コストも安価で修景効果も高く, 強健な植物として知られ るハナショウブ (Iris ensata Thunb.) の 2 種類のアヤメ科植物 を供試植物とし基礎的な $\mathrm{Cd}$ 吸収除去能力を明らかにする。また Cd 而性の無い植物は枯死または著しく生育に支障をきたすこと が報告されていることから ${ }^{5)}, \mathrm{Cd} に よ る$ 供試植物の植物体自体 への生育阻害について, 肉眼による茎葉部及び根部の被害状況の 観察と色彩色差計を用いた葉色の変化の観察, 並びに細胞レベル
での障害を見る一指標として位置付けられている電解質溶出率の

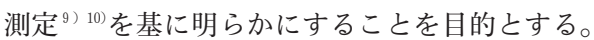

\section{2. 実験方法}

\section{(1) 実験区概要}

供試植物の $\mathrm{Cd}$ 吸収除去能力を迅速に調べるため，水耕液中の $\mathrm{Cd}$ 吸収除去実験を行った。キショウブとハナショウブは開花時 期が異なるため，生育周期から見て同一条件とするため，それぞ れ花後の分けつ期 ${ }^{6}$ に入ったと思われる時点で実験を開始した。 つまり, キショウブは 2005 年 6 月 27 日から 7 月 4 日まで，八ナ ショウブは 2005 年 8 月 27 日から 9 月 3 日にかけて行った。実験 場所は東京農業大学内温度調節ガラス室（キショウブ実験時 平 均気温 $24.2 \pm 6.6^{\circ} \mathrm{C}$ 湿度 $57.5 \pm 20.8 \%$ ハナショウブ実験時 平 均気温 $29.1 \pm 4.4^{\circ} \mathrm{C}$ 湿度 $\left.62.3 \pm 15.9 \%\right)$ にて行った。実験には ポリプロピレン製の容器 $(200 \times 200 \times 100 \mathrm{~mm})$ を使用した。各 実験区及び供試植物を写真 -1 に示す。

\section{（2）供試個体}

キショウブ, ハナショウブ共に市販のポット苗を用い,生育が同 程度のものを選び供試した。全ての供試植物は 1 株ずつ発泡スチ ロールに穴を開けたものに固定し，3 反復実験を行った。供試植 物は水耕液中で 7 日間の養生を行った後, 先行研究 ${ }^{7}$ を参考に 7 日間のCd処理を行い，濃度の違いによるCd吸収除去実験を行った。

\section{（3）水耕液及び $C d$ 濃度}

養生期間中の水耕液は大塚八ウス肥料 1 号〔保証成分（\%) N

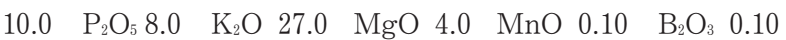
配合成分 (\%) Fe $0.18 \mathrm{Cu} 0.002 \mathrm{Zn} 0.006 \quad \mathrm{Mo}$ 0.002], 同 2 号〔保証成分（\%） N 11.0 配合成分（\%) $\mathrm{CaO}$ 23.0〕を用い, 汎用性の高い処方（1000 当たり 1 号 $1500 \mathrm{~g}: 2$ 号 1000g）を採用 し各容器に 3 入れた。植物体の蒸発散に伴う水耕液の減少分は 純水を添加し, 総量が常に 3 となるよう調整した。水質の維持 は $\mathrm{pH} 5.5 \sim 6.0, \mathrm{EC} 2.2 \mathrm{dS} / \mathrm{m}$ 程度に各容器の水耕液を一定に保ち,

\footnotetext{
${ }^{*}$ 東京農業大学大学院農学研究科 ${ }^{* *}$ 東京農業大学地域環境科学部造園科学科
} 


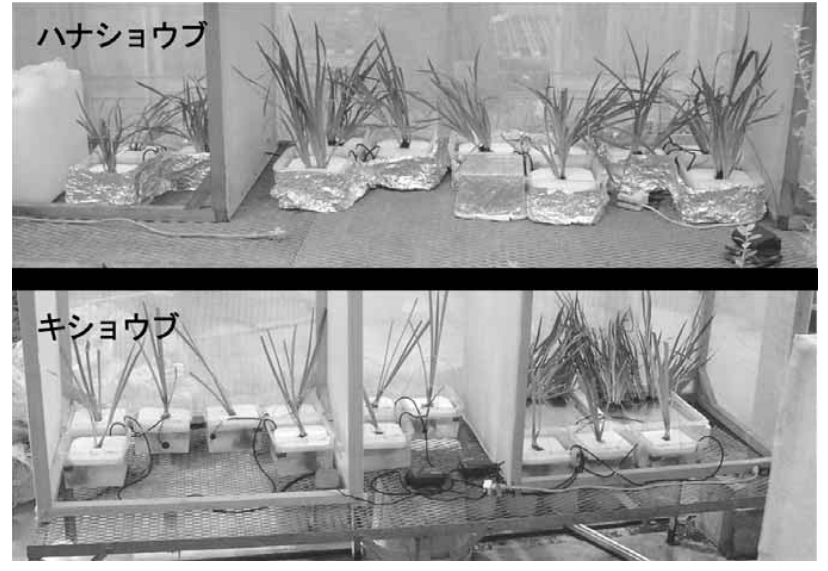

写真-1 各実験区の供試植物

全ての実験区で連続的にエアーポンプ及びエアーストーンを使用 し, 水耕液内に直接エアレーション（1.0/ min）を行った。実 験に使用する水耕液の $\mathrm{Cd}$ 濃度は, $\mathrm{Cd}$ 耐性を持たない植物は 100 $\mu \mathrm{M}(11.24 \mathrm{ppm})$ 前後で枯死や生育に支障をきたす報告 ${ }^{5)}$ やホテ イアオイが $100 \mathrm{ppm}$ 以上で急性毒性 ${ }^{8)}$ を示した報告もあることか ら，1ppm，10ppm，100ppm の 3 段階に設定し, 各実験区の設 定濃度になるように, 塩化カドミウム $\left(\mathrm{CdCl}_{2}\right)$ 水溶液を純水に 添加し使用した。また Cd 無施用区（対照区）も設置した。

\section{(4) Cd の定量方法}

植物体からの $\mathrm{Cd}$ 抽出は植物体を茎葉部と根部に切り離し, 植 物体に直接付着した水溶液中の $\mathrm{Cd}$ を完全に除去するため中性洗 剂を用いて洗浄後, 超純水で十分に濯ぎを行った後, ドライオー ブンで試料を完全乾燥後, 粉砕した。乾燥試料 $1 \mathrm{~g}$ を硫酸 - 過酸 化水素水にて湿式灰化処理を行い, 原子吸光光度計 (島津製作所 製 $\mathrm{AA}$ - 680）にて茥葉部と根部の $\mathrm{Cd}$ の定量を行った。

\section{（5）色彩色差計での測定}

$\mathrm{Cd}$ による供試植物の葉色の変化を肉眼による観察だけではな く, 色に関するパラメーターの変化から明らかにするため, 葉の 色調, 色度を計測した。測定は各ポットの供試植物を色彩色差計 （ミノルタカメラ販売 (林) 製 CR-200b）の $\mathrm{L}^{*} \mathrm{a}$ *b*表色系を用い, 茎葉部を無作為に 9 点選出し添加前後で測定した。測定結果は各 実験区の明度指数 $\mathrm{L}^{*}$, クロマティクネス指数 $\mathrm{a}^{*}, \mathrm{~b}^{*}$ とそれらか ら算出した彩度 $\mathrm{C}^{*}\left\{\mathrm{C}^{*}=\left(\mathrm{a}^{* 2}+\mathrm{b}^{* 2}\right)^{1 / 2}\right\}$ の平均值を用いて表した。

\section{（6）電解質溶出率の測定}

$\mathrm{Cd}$ による供試植物への影響を細胞レベルで見る一指標として 電解質溶出率を求めた。養生を開始して 7 日目と $\mathrm{Cd}$ を添加して 7 日目の計 2 回, 茎葉部に直径 $5 \mathrm{~mm}$ のパンチで 5 枚のリーフディ スクを採取し, $100 \mathrm{ml}$ の蓋付きバイアル瓶に超純水を $30 \mathrm{ml}$ 加え, 暗室 10 下で 24 時間静置後, $25^{\circ} \mathrm{C}$ 下で 30 分間の振晹により電解

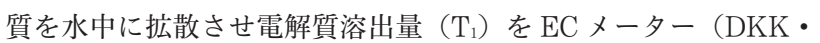
TOA CM - 60G）で測定した。その後オイルバスで 15 分間煮 沸し, 再度電解質溶出量 $\left(\mathrm{T}_{2}\right)$ を測定 ${ }^{9) 10} し$, この $\mathrm{T}_{1} / \mathrm{T}_{2}$ の值を 電解質溶出率（\%) とした。この值が大きいほど細胞が被害を受 けている可能性が高いことを示す ${ }^{9)}$ 。

\section{3. 実験結果及び考察}

（1）供試植物体内の $\mathrm{Cd}$ 濃度, $\mathrm{Cd}$ 集積割合

$\mathrm{Cd}$ 処理濃度 $1,10,100 \mathrm{ppm}$ の溶液中で 1 週間生育した後の キショウブ及び八ナショウブの 1 個体当たりの茎葉部及び根部の $\mathrm{Cd}$ 濃度と $\mathrm{Cd}$ 集積割合を実験区ごとにまとめたものを, それぞ れ図 $-1,2$ に示す。

キショウブ, ハナショウブ共に実験区の水耕液中の $\mathrm{Cd}$ 濃度が

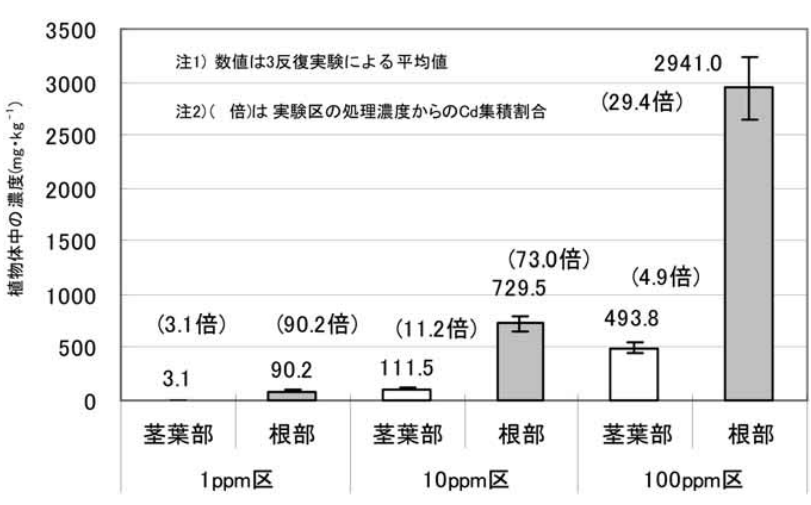

図-1 キショウブ体内の $\mathrm{Cd}$ 濃度

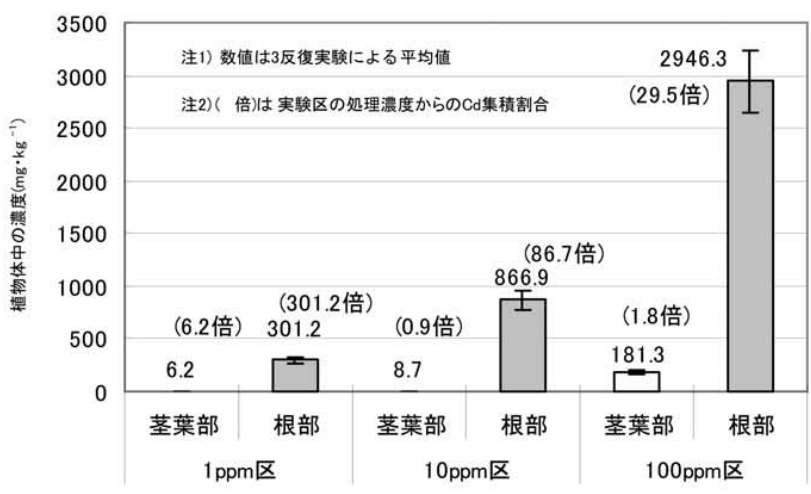

図－２ハナショウブ体内の Cd 濃度

高まるにつれて茎葉, 根部共に体内の $\mathrm{Cd}$ 濃度は顕著に増加した。 キショウブの $1 \mathrm{ppm}$ 区では，その処理濃度に対して茎葉部で 3.1 倍, 根部で 90.2 倍, $10 \mathrm{ppm}$ 区では茎葉部で 11.2 倍, 根部で 73.0 倍, $100 \mathrm{ppm}$ 区では茥葉部で 4.9 倍, 根部で 29.4 倍であり, 設定 した処理濃度に対して茎葉部では $10 \mathrm{ppm}$ 区，根部では $1 \mathrm{ppm}$ 区 が最も $\mathrm{Cd}$ 集積割合が高く，八ナショウブの $1 \mathrm{ppm}$ 区では，その 処理濃度に対して茎葉部で 6.2 倍, 根部で 301.2 倍, $10 \mathrm{ppm}$ 区で は茎葉部で 0.9 倍, 根部で 86.7 倍, $100 \mathrm{ppm}$ 区では茎葉部で 1.8 倍, 根部で 29.5 倍であり, 設定した処理濃度に対して $1 \mathrm{ppm}$ 区 の茎葉部と根部で最も $\mathrm{Cd}$ 集積割合が高い結果となった。

（2）供試植物の乾燥重量及び植物体中 Cd 重量, Cd 除去率

$\mathrm{Cd}$ の定量後にキショウブ及びハナショウブの $\mathrm{Cd}$ 除去能力を 数值によって比較するため, 供試植物の 1 個体及び単位乾燥重量

\section{表 - 1 植物体中 Cd 重量及び Cd 除去率を求める算定公式}

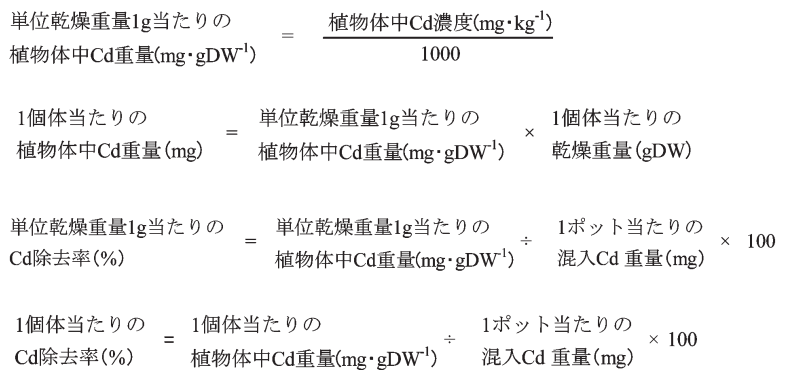


表 -2 各供試植物の乾燥重量及び植物体中 C d 重量, 除去率

\begin{tabular}{|c|c|c|c|c|c|c|c|c|c|c|c|c|c|c|c|}
\hline \multirow[t]{2}{*}{ 供試植物名 } & \multirow[t]{2}{*}{ 実験区 } & \multirow{2}{*}{$\begin{array}{l}1 \text { ポット当たりの } \\
\text { 混入Cd重量(mg) }\end{array}$} & \multicolumn{5}{|c|}{ 1個体当たりの植物体中Cd重量(mg) } & \multicolumn{3}{|c|}{ 1個体当たりの乾燥重量(gDW)* } & \multicolumn{3}{|c|}{$\begin{array}{l}\text { 単位乾燥重量1 } 1 \mathrm{~g} \text { 当たりの } \\
\text { 植物体中 } \mathrm{C} \text { 重量(mg.gDW-1') }\end{array}$} & \multirow{2}{*}{$\begin{array}{l}\text { 単位乾燥重量1g } \\
\text { 当たりのCd除去率(\%) }\end{array}$} & \multirow{2}{*}{$\begin{array}{l}\text { 1個体当たりの } \\
\text { Cd除去率 }(\%)\end{array}$} \\
\hline & & & 全体 & 莰葉部 & & 根部 & & 全体 & 蓕葉部 & 根部 & 平均值** & 茎葉部 & 根部 & & \\
\hline \multirow[t]{3}{*}{ キショウブ } & 1ppm区 & 3.00 & 0.847 & 0.015 & $(1.8)$ & 0.832 & (98.2) & 14.09 & 4.85 & 9.24 & 0.060 & 0.003 & 0.090 & 2.00 & 28.23 \\
\hline & 10ppm区 & 30.00 & 5.976 & 0.421 & $(7.0)$ & 5.555 & (93.0) & 11.37 & 3.76 & 7.61 & 0.526 & 0.112 & 0.730 & 1.75 & 19.92 \\
\hline & 100ppm区 & 300.00 & 18.745 & 2.040 & $(10.9)$ & 16.705 & $(89.1)$ & 9.81 & 4.13 & 5.68 & 1.911 & 0.494 & 2.941 & 0.64 & 6.25 \\
\hline \multirow[t]{3}{*}{ ハナショウブ } & 1ppm区 & 3.00 & 1.482 & 0.040 & $(2.7)$ & 1.442 & (97.3) & 11.41 & 6.62 & 4.79 & 0.130 & 0.006 & 0.301 & 4.33 & 49.40 \\
\hline & 10ppm区 & 30.00 & 4.638 & 0.043 & $(0.9)$ & 4.595 & (99.1) & 10.08 & 4.78 & 5.30 & 0.460 & 0.009 & 0.867 & 1.53 & 15.46 \\
\hline & 100ppm区 & 300.00 & 15.705 & 1.093 & $(7.0)$ & 14.612 & $(93.0)$ & 11.00 & 6.04 & 4.96 & 1.428 & 0.181 & 2.946 & 0.48 & 5.24 \\
\hline
\end{tabular}

注1) 数值は3反復実験による平均値 注2)（ )内は1個体当たりの植物体中Cd重量 $(\mathrm{mg})$ の全体に対してのパーセンテージ

* 全ての実験区は $5 \%$ 水準で有意差無し(Duncan)

$* *$ 茎葉部と根部を合わせ算出した単位乾燥重量 $1 \mathrm{~g}$ 当たりのCd重量の平均値 $=1$ 個体当たりの植物体中Cd重量の全体 $/ 1$ 個体当たりの乾燥重量の全体

$1 \mathrm{~g}$ 当たりの植物体中 $\mathrm{Cd}$ 重量 $(\mathrm{mg})$ 求め, さらに 1 ポット当た りの混入 $\mathrm{Cd}$ 量からどの程度 $\mathrm{Cd}$ を除去したかを表すため, 植物 体の大きさに影響されない単位乾燥重量 $1 \mathrm{~g}$ 当たりの $\mathrm{Cd}$ 除去率 $(\%)^{11)}$ 之実際の $\mathrm{Cd}$ 除去率に当たる 1 個体当たりの $\mathrm{Cd}$ 除去率 $(\%)^{12}$ を 4 つの式から求めた (表一 1 )。各実験区の実験終了時の 1 個体当たりの乾燥重量 (gDW), 1 個体及び単位乾燥重量 $1 \mathrm{~g}$ 当 たりの植物体中 $\mathrm{Cd}$ 重量 $(\mathrm{mg})$ さらに単位乾燥重量 $1 \mathrm{~g}$ 及び 1 個 体当たりの $\mathrm{Cd}$ 除去率（\%) を求めた結果を表－2 に示す。

1 個体当たりの植物体中の茥葉部之根部の $\mathrm{Cd}$ 重量 $(\mathrm{mg})$ か ら各供試植物の部位別の $\mathrm{Cd}$ の吸収割合を求めた結果, キショウ ブでは 7 日間で植物体中へ吸収された $\mathrm{Cd}$ の内, 処理濃度（実験 区）によって若干異なるが 1.8 10.9\%が茎葉部に，ハナショウ ブでは $0.9 \sim 7.0 \%$ が茎葉部に吸収されていた。

以上のことから短期間の $\mathrm{Cd}$ 吸収除去実験ではキショウブ，八 ナショウブ共に植物体中 $\mathrm{Cd}$ のほとんどが根部に吸収され, 特に 八ナショウブにおいてその傾向が大であることが明らかとなった。

単位乾燥重量 $1 \mathrm{~g}$ 当たりの $\mathrm{Cd}$ 除去率（\%）はキショウブ，八 ナショウブ共に $1 \mathrm{ppm}$ 区で最も除去率が高い結果となった。ま た $1 \mathrm{ppm}$ 区では八ナショウブの吸収除去率が高かったが, $10 \mathrm{ppm}$ 区や特に $100 \mathrm{ppm}$ 区では後述する $\mathrm{Cd}$ 処理による様々な生育阻害 が現れキショウブの単位乾燥重量 $1 \mathrm{~g}$ 当たりの Cd 除去率 (\%) や 1 個体当たりの Cd 除去率（\%) でも下回る結果となった。 ちなみに前回報告 ${ }^{11}$ ) したアジュガ, ミゾソバの単位乾燥重量 $1 \mathrm{~g}$ 当たりの Cd 除去率（\%) と比較するとキショウブ，八ナショウ ブ共に全ての実験区に抢いて高い結果となり, さらに 1 個体当た りの $\mathrm{Cd}$ 除去率（\%）に換算し比較すると植物体が大きく，その 乾燥重量が大であるキショウブ，ハナショウブは全ての実験区で アジュガやミゾソバのそれを大きく上回る結果となった。特に八 ナショウブの $1 \mathrm{ppm}$ 区の 1 個体当たりの Cd 除去率（\%) はアジュ ガの 28.6 倍, ミゾソバの 19.6 倍。キショウブの 1 個体当たりの $\mathrm{Cd}$ 除去率（\%）は $10 \mathrm{ppm}$ 区でアジュガの 39.1 倍, ミゾソバの 48.6 倍。100ppm 区でアジュガの 12.5 倍, ミゾソバの 27.2 倍と 非常に高い結果となった。

\section{（3）供試植物の Cd による生育への影響}

供試植物の $\mathrm{Cd}$ よる生育への影響を茎葉部及び根部の変化から 観察するため, 肉眼による茎葉部及び根部の観察を行った結果, キショウブは全ての実験区で肉眼で確認できるような生育被害は 認められなかったが，ハナショウブでは $100 \mathrm{ppm}$ 区の供試した 個体全てに茎葉部の黄化現象や茎葉部の一部に枯損あるいは萎れ が見られ Cd による生育阻害が確認された。（写真－2，3）なお 根部に関しては全ての実験区で肉眼で確認できるような生育被害 は認められなかった。

したがって色彩色差計を用いた葉色の測定でもキショウブは各 実験区共に顕著な葉色の変化は認められず, 八ナショウブの $100 \mathrm{ppm}$ 区でのみ色調はあざやか（vivid）の方向へ傾き, 色度で は黄方向への傾きが確認された。（図－3，4）

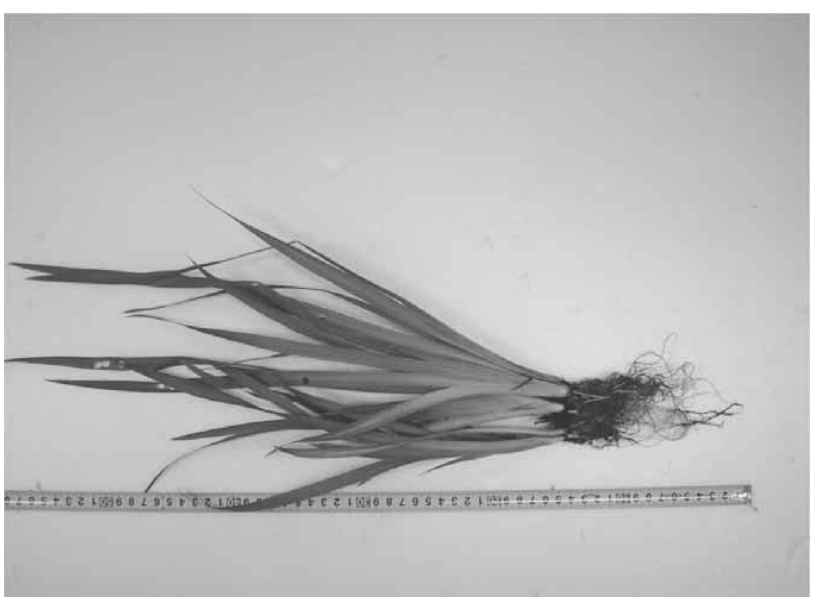

写真－２＼cjkstart実験終了時のハナショウブ（対照区）

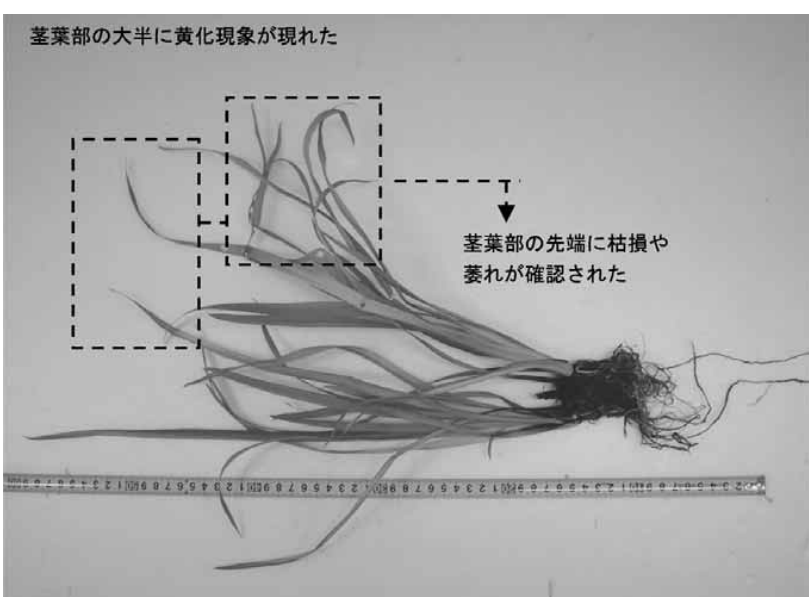

写真－３＼cjkstart実験終了時のハナショウブ（100ppm 区）

各供試植物の $\mathrm{Cd}$ にる細胞への影響を明らかにするため, 各供 試植物の電解質溶出率（\%) を測定した結果を表－3に示す。キ ショウブでは $\mathrm{Cd}$ 添加前, 後ともに対照区と各濃度区で電解質溶 質率（\%）に大きな差はなかったが，ハナショウブでは Cd 添加 後, $100 \mathrm{ppm}$ 区でのみ対照区及びその他の区よりも電解質溶出率 （\%）は高い值を示し，細胞レベルでも Cdによる生育への影響 が現れていることが確認された。

以上のことから 7 日間の $\mathrm{Cd}$ 処理でキショウブは $100 \mathrm{ppm}$ でも 生育阻害を受けず，一方，八ナショウブは $100 \mathrm{ppm}$ でかなりの 生育阻害が認められることが明らかとなった。 

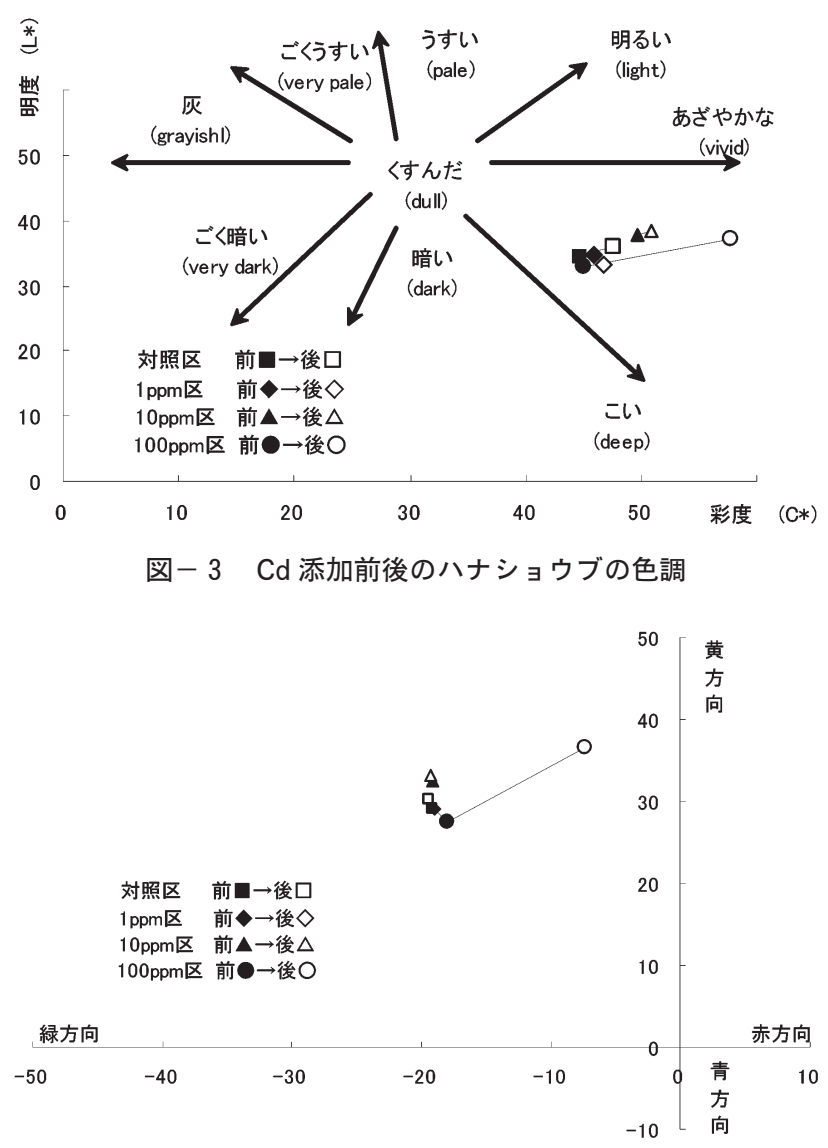

図－4 Cd 添加前後のハナショウブの色度

表 -3 各供試植物の $\mathrm{Cd}$ 施用前後の電解質溶出率（\%）

\begin{tabular}{lccc} 
供試植物名 & 実験区 & Cd施用前 & Cd施用後 \\
\hline キショウブ & 対照区 & $10.36 \mathrm{a}$ & $11.92 \mathrm{a}$ \\
& 1ppm区 & $11.09 \mathrm{a}$ & $13.13 \mathrm{a}$ \\
& 10ppm区 & $17.28 \mathrm{a}$ & $14.41 \mathrm{a}$ \\
& 100ppm区 & $10.57 \mathrm{a}$ & $16.30 \mathrm{a}$ \\
\hline ハナショウブ & 対照区 & $11.28 \mathrm{a}$ & $14.86 \mathrm{a}$ \\
& 1ppm区 & $11.18 \mathrm{a}$ & $12.17 \mathrm{a}$ \\
& 10ppm区 & $10.20 \mathrm{a}$ & $11.47 \mathrm{a}$ \\
& 100ppm区 & $10.31 \mathrm{a}$ & $22.24 \mathrm{~b}$ \\
\hline
\end{tabular}

注1)数值は3反復実験による平均値

注2)異なるアルファベット間は5\%水準で有意(Duncan)

なお，本実験は 2 種の異なる植物の生育周期を合わせることを 意図して実験を行った結果, 実験時期と温度条件が異なり, その ことによって厳密に言えば蒸散速度などの生理作用も影響を受け, $\mathrm{Cd}$ の吸収量や生育阻害の程度にも若干, 影響が出たと考えられ なくもないが, 類似の研究事例もなく, この点の究明は次回の研 究課題としたい。

\section{4. 結論}

開花後の分けつ期に入ったと思われる時期における 7 日間の $\mathrm{Cd}$ 処理実験の結果, キショウブ, 八ナショウブ共に茥葉部より 屯根部の $\mathrm{Cd}$ 吸収量が極めて大きいことが明らかとなった。各供 試植物の単位乾燥重量 $1 \mathrm{~g}$ 当たりの $\mathrm{Cd}$ 除去率（\%) では $1 \mathrm{ppm}$ 区で八ナショウブがキショウブよりも高い除去率を示したが, 実 験区の $\mathrm{Cd}$ 処理濃度が $10 \mathrm{ppm}$ 区，100ppm 区と高まるにつれて 八ナショウブはキショウブより除去率が下回る結果となった。

各供試植物の $\mathrm{Cd}$ による生育への影響は, ハナショウブは 100ppm 区に扔いて黄化現象や電解質溶出率（\%) など茥葉部の 葉色や細胞レベルでの顕著な生育阻害が現れたのに対し, キショ ウブは目立った生育阻害は確認されなかった。

以上のことから各供試植物を比較すると, 本実験の設定の範囲 内では Cd 耐性についてはキショウブが優れ，ハナショウブに生 育阻害が発現するような高濃度の Cd 污染地などに対して導入が 可能となる。一方, 八ナショウブは生育阻害が現れない低濃度の $\mathrm{Cd}$ 污染地ではキショウブよりも効率的な浄化が期待できると考 えられる。さらに前回の報告において Cd 除去率が高い Hyperaccumulator（重金属超集積性植物）とされたアジュガ，ミゾソ バに比べて単位乾燥重量 $1 \mathrm{~g}$ 当たりの $\mathrm{Cd}$ 除去率（\%）は全ての 実験区で高い結果となった。さらにキショウブ，ハナショウブ共 に植物体が大きく, その乾燥重量が大であるため, 実際の $\mathrm{Cd}$ 除 去率に当たる 1 個体当たりの $\mathrm{Cd}$ 除去率（\%) では大きく上回り, $\mathrm{Cd}$ のファイトレメディエーターとして極めて有望であることが 示唆された。

今後の課題として, 生育周期や温度条件の違いと $\mathrm{Cd}$ 吸収量, 生育阻害の程度との関係の究明，並びに $\mathrm{Cd}$ 処理濃度期間を長く 設定し， Cd の茥葉部や根部への集積度合いや割合についてさら に詳しく解明を進め, 茎葉部への集積度合いなどが増加するよう であれば刚り取り再生を, 変化がない場合は茎根とも除去するこ とを想定した検討をしていきたいと考えている。

\section{引用・参考文献}

1) 独立行政法人農業環境技術研究所ホームページ : $\langle$ http://ss.niaes. affrc.go.jp/magazine/064/mgzn06406.html〉, 20 05.8.1 更新. 2005. 10.20 参照

2 ) 国立医薬品食品衛生研究所ホームページ :〈http://www.nihs.go.jp/ DCBI/PUBLIST/ehchsg/ehctran/tran1/cadmium.html〉, 1997.1.7 更新. 2005.10.10 参照

3 ）杉山 恵・阿江教治（2004）：カドミウム污染土壌に対するファイトレ メディエーションの有効性と問題点：第 21 回土・水研究会資料 農 耕地における重金属污染土壤の修復技術の現状と課題：独立行政法 人農業環境技術研究所, 8-14

4 ）田村良三・北嶋永一・王沢 斌（2002）：植物を利用した水質浄化シス テム（第 4 報） - 水質浄化に適する植物及び水路の自浄作用一: 新潟 県保健環境科学研究所年報第 17 卷, 89-93

5 ）今中忠行 - 森川弘道・斎藤和季・佐治 光 - 中里広幸・長谷川功・西 村 実 (2000)：植物による環境負荷低減技術：NTS, 189-204

6 ）冨野耕治（1975）：NHK 趣味の園芸 作業 12 か月・.(2)八ナショウブ : NHK 出版, 2-5

7 ) Fumie Shinmachi, Yuki Kumanda, Akira Noguchi and Isao Hasegawa (2003) : Translocation and accumulation of cadmium in cadmium-tolerant polygonum thunbergii: Soil Science Plant Nutr., 49 (3), 355-361

8 ) O'Keeffe D. H. , Hardy J. K. , Rao R. A. , (Univ. Akron, OH) (1984) : Cadmium uptake by the water hyacinth : Effects of solution factors. : Environmental Pollutant Ser A. , 34(2), 133-147

9 ) 今田成雄 (2003)：高温環境下に㧍ける野菜の生理・生体反応：農業 及び園芸 78 (8)，858-863

10）岡部昭典：一枚の葉からホウレンソウの耐暑性を評価する:独立法人 農業・生物系特定産業技術研究機構ホームページ：〈http://www.cg k.affrc.go.jp/news/127/kenkyuu3/kenkyuu3.html〉, 1999 更新 . 2004.10.1 参照

11）浅井俊光・高橋良和・水庭千鶴子・近藤三雄（2005）：アジュガ (Ajuga reptans L.) による水耕液中のカドミウムの吸収除去に関す る研究：ランドスケープ研究 68(5), 537-540

12）浅見輝男（2001）：データで示す一日本土㙵の有害金属污染：アグネ 技術センター, 132 -133 